Marmara Üniversitesi

İ.̇.B. Dergisi

YIL 2015, CILT XXXVII, SAYI I, S. 125-147

Doi No: 10.14780/iibd.83419

\title{
REGIONAL INEQUALITIES IN TURKEY: POST 2001 ERA
}

\author{
Burhan Can KARAHASAN*
}

\begin{abstract}
This paper examines the path of the regional inequalities in Turkey for the post 2001 period. After the financial turmoil and the sharp downturn in the economy in 2001, Turkey managed to sustain $3.6 \%$ real per capita GDP growth between 2002 and 2014. Even the increase in the GDP is remarkable the way that the growth is distributed at the regional scale is questionable. Originating from the concern on the ability of Turkish regions to equally benefit from the economic growth, regional inequalities are evaluated via regional wage income differences at NUTS II disaggregation for the 2003-2008 period. Even initial set of analysis point out a fall in the regional wage income gaps, a careful interpretation indicate the persistence of the heterogeneous pattern coming from the pre-2001 period. Analysis covering all industries indicates that, out of the 26 sub-regions, 5 of the NUTS II regions in the eastern Turkey move to a group of regions with lower wage income during the 2003-2008 period. Meanwhile neither the high wage region clusters nor the outlier regions acting as geographic transitions do realize a significant movement within the distribution. Results are much or less consistent for manufacturing production as well. In general findings underline a period of ongoing polarization in the wage income at NUTS II level during the post 2001 period in Turkey. Additionally results also highlight the non-randomness of this polarization even at NUTS II disaggregation which once more points out that spatial dependence and spatial heterogeneity works together in Turkey.
\end{abstract}

Keywords: Inequality, Panel Data, Spatial Regime, Turkey.

JEL Classification: R11, R12.

\section{TÜRKIYYE'DE BÖLGESEL EŞITSİZLIKLER: 2001 SONRASI DÖNEM}

$\ddot{O}_{z e t}$

Bu çalışma 2001 sonrası dönemde Türkiye’ de bölgesel farklılıkların patikasını incelemektedir. 2001 yılında yaşanan finansal kriz ve ekonomideki hizl gerileme son-

* Assistant Professor, Piri Reis University, Department of Economics and Finance, Tuzla, İstanbul, bckarahasan@pirireis.edu.tr 
rası, 2002 ve 2014 yılları arasında Türkiye \% 3.6'lık reel kişi başı GSYH artışı yaşamayı başarmıştır. Ancak bu büyüme ciddi olsa da, büyümenin bölge düzeyinde nasıl dağıldı bir soru olarak karşımıza çıkmaktadır. Bu çalışmada Türkiye’ de bölgelerin yaşanan bu büyümeden ne derecede faydalanabildiği tartışmasından yola çıkllarak, IBBS II' de 2003-2008 ylllarl arasında yaşanan ücretli gelir eşitsizliği incelenmektedir. İlk bulgular ücretli gelir dağılımında bir düzelmeyi işaret etse de, detaylı incelemeler 2001 yılı öncesi yaşanan heterojen yapının 2003-2008 döneminde de sürdüğ̈̈nü göstermektedir. Tüm sektörleri kapsayan incelemeler 26 alt bölge içinden 5 doğu bölgesinin bu dönemde daha düşük seviyeli ücretli gelire sahip olan gruba indiğini göstermektedir. Bunun ile birlikte ne yüksek ücretli gelire sahip olan bölgelerde ne de bulundukları coğrafyaya aykırı davranan coğrafi geçiş bölgelerinde dağılım içinde anlamlı bir hareket görülmemiştir. Genel olarak bulgular IBBS II düzeyinde incelenen ücretli gelir dağllımının Türkiye’ de 2001 yılı sonrasında bir polarizasyon sürecinden geçtiğini göstermektedir. Ayrıca bulgular bu polarizasyonun IBBS II düzeyinde dahi rastlantısal olmadı ğını, mekânsal băg ve farklılaşmanın Türkiye’ de beraber işlediğini işaret etmektedir.

Anahtar Kelimeler: Eşitsizlik, Mekânsal Sistem, Panel Veri, Türkiye.

JEL Sinıflamasi: R11, R12.

\section{Introduction}

Turkish economy was hit heavily by the financial turmoil of 2001. After the 1994 crisis and the unsuccessful 1999 stabilization attempts the economy enters into a downturn during the beginning of 2000s. ${ }^{1}$ The severe economic conditions are also coupled by the 1999 Marmara Earthquake which directly affected the so-called manufacturing belt in the Marmara Region. Under these circumstances, with the start of the implementation of the new economic policies Turkey take in a recovery period during the last decade. Yet even the 2002-2014 period witnessed a 3.6\% annual growth in per capita terms; growth tends to slow down from $5.5 \%$ in $2002-2007$ to $1.9 \%$ in 2008 2014. Moreover little is known on the impact of the recovery period on the numerous socio-economic troubles of Turkey. Among various discussed items regional imbalances also deserves a careful interpretation.

Regional imbalance concern of Turkey stands on the agenda of the economic policy makers for decades. As discussed by Doğruel ${ }^{2}$ the dual structure of the Turkish regions are discussion points starting from the early planned development period of the country. However as deliberated by Doğruel $^{3}$ policy implementations like the use

1 Fikret Şenses, "Economic Crisis as an Instigator of Distributional Conflict: The Turkish Case in 2001", The Turkish Economy in Crisis, Eds. Öniş Z. and Rubin B., Routledge, 2003, pp. 92-120.

2 Fatma Doğruel, “Türkiye'de Bölgesel Politikalar", Değişen Türkiye Dönüşen Mekan, Ed. A. Eraydın, 2006, Dost Kitapevi Yayınları, pp. 164-195.

3 Fatma Doğruel, Bölgesel Kalkınma ve Kalkınma Ajansları, TÜRKONFED Yayınları, 2012. 
of Regional Development Agencies (RDAs) are not sufficient to close the gap among the rich and poor regions of Turkey. With the influential contribution of Barro and Sala-i Martin ${ }^{4}$, the neo-classic explanation to the convergence issue, number of case studies investigating the path of regional inequalities as well as the possibility of the poor regions to catch up with the rich ones gain increasing attention. Doğruel and Doğruel $^{5}$, Gezici and Hewings ${ }^{6}$, Yıldırım and Öcal ${ }^{7}$ indicate some signs of decrease in regional inequalities for the pre 2001 period. However these studies also documented that the slow convergence signs are far away from significantly closing the gap between lagging eastern regions and the relatively more prosperous western geography. Similarly other than the regional income differences, studies of Filiztekin ${ }^{8}$, Karahasan and Uyar $^{9}$, Yeşilyurt and Elhorst ${ }^{10}$, Karahasan ${ }^{11}$, Bilgel and Karahasan ${ }^{12}$ dealing with different socio-economic problems of Turkey at the regional scale also validates that; the dichotomy observed in the income pattern is reflected directly to other issues such as education, employment, local demand, industrial development and security concerns among others.

In a way to complement these analyses, it seems to be a necessity to consider the path of the regional inequalities for the recent recovery era during which Turkey is observed to be realizing a rapid growth and change in its economic and social fundamentals. While doing this the study aims at focusing on the regional wage income dispersion from 2003 to 2008. The aggregation level will be NUTS II classification. An important dimension that will be considered is the spatial regimes issue with specific emphasis on the spatial links as well as spatial heterogeneity. Even the

4 Robert J. Barro and Xavier Sala-i Martin, “Convergence”, Journal of Political Economy, Vol.100, No.2, 1992, pp.223-251.

5 Fatma Doğruel and Suut Doğruel, “Türkiye'de Bölgesel Gelir Farklılıkları ve Büyüme”, İktisat Üzerine Yazılar I Küresel Düzen: Birikim, Devlet ve Sınıflar Korkut Boratav'a Armağan, Eds. A.Köse, F.Şenses, E.Yeldan, 2003.

6 Ferhan Gezici and Geoffrey J.D. Hewings, "Regional Convergence and Economic Performance of Peripheral Areas in Turkey", Review of Urban \& Regional Development Studies, Vol.16, No.2, 2004, pp.113-132.

7 Julide Yıldırım and Nadir Öcal, "Income Inequality and Economic Convergence in Turkey”, Transition Studies Review, Vol.13, No.3, 2006, pp.559-568.

8 Alpay Filiztekin, "Regional Unemployment in Turkey", Papers in Regional Science, Vol.88, No.4, 2009, pp.863-878.

9 Burhan Can Karahasan and Emrah Uyar, "Spatial Distribution of Education and Regional Inequalities in Turkey", Munich Personal RePEc Archive, No.30130, 2009.

10 Filiz Yeşilyurt and J. Paul Elhorst, "A Regional Analysis of Inflation Dynamics in Turkey”, The Annals of Regional Science, Vol.52, 2014, 1-17.

11 Burhan Can Karahasan, "Dynamics of Regional New Firm Formation in Turkey”, Review of Urban \& Regional Development Studies, Vol. 27, No.1, 2015, pp. 18-39.

12 Firat Bilgel and Burhan Can Karahasan, "The Economic Costs of Separatists Terrorism in Turkey", Journal of Conflict Resolution, 2015, DOI: 10.1177/0022002715576572, 2015. 
data aggregation level is a concern, some basic spatial data analysis tools are going to be carried out to control for the impact of geography as well as spatial regimes in the regional inequality discussion. This approach is expected to contribute to the regional inequality discussion in Turkey from various dimensions. First of all, given the data availability issues which will be carefully handled throughout the text, most of the studies dealing with the regional inequality problem examine the pre 2001 period. Secondly our knowledge on the importance of spatial ties as well as spatial heterogeneity is limited for the case of Turkey. The impact of spatial regimes as well as spatial heterogeneity should be of the concern of the policy making scheme especially at the local level. Finally findings are expected to shed light on the impact of the post 2001 economic policies on one of the most remarkable problems of regional inequality in Turkey which Turkish economy has been continuously struggling with during the last decades.

This paper will continue as follows: section 2 briefly outlines the historical origins of regional inequalities in Turkey. The influential discussions among Turkish scholars on the topic are going to be refined and the path of inequalities is going to be evaluated. Section 3 will first introduce the data set by explaining the time and industrial scope of the analysis. Next section 3 will outline the basic statistical analysis and the analytical framework of the empirical part of the research. Section 4 will give the results to create the discussion part of the research. This section will also include a detailed interpretation of the spatial regimes and heterogeneity as well as their possible influence on the regional policy making. The paper will end with a conclusion.

\section{Historical Origins of Regional Inequalities in Turkey}

Regional inequalities have been on the agenda of regional scientists for ages in Turkey. The interest of the scholars on the matter is not alone by itself. It has also been the case that policy makers take into account the extent of the regional imbalances, as development plans of both the planned period as well as the later liberalization era contains the regional inequality problem under the socio-economic concerns of the country. Among different implementations the Priority Development Areas (PDAs) which gives different incentive measures to lagging areas of Turkey is one popular implementation of the period. However evidence for the pre 2001 period underlines that policy implementations are far away from having influence to decrease the widening income gaps. Meanwhile during the last episode of post 2001 during which Turkey realizes rapid change in its institutional and social environment regional inequality problem also finds its place within the development policy making scheme. The active use of Regional Development Agencies (RDAs) and the attempt of Ministry of Development (MOD) to examine the regional socio-economic development differences are similar to the early areas as underlining the continuity of the awareness of policy makers regarding the problem of regional disparities. However as discussed, we have little knowledge on the success of the recent set of attempts as well as awareness on the matters. 
Tekeli $^{13}$ discussed the regional inequality problem in Turkey and argued that among various reasons, the cut of the ties with the eastern countries during the first republican era is one of the reasons behind the lagging development of the eastern geography of Turkey. The collapse of the ties with Caucasus and Aleppo after the Ottoman Period is observed to be a remarkable reason for that. Similarly loss of active working age young population during the war periods is discussed to be a cause behind the deepening of the regional imbalances. It would also not be inaccurate to also argue that given the restructuring process of the early republic period resources are directed to locations with already developed (relatively) fundamentals. That is the early years of the Turkish economy after its foundation has a structure which is able to create an unequal dispersion of income and wealth in a circular manner. Given all these developments Turkish literature mostly covering the 1975 and 2001 period indicates that regional income patterns are in a way realizing a deepening heterogeneity. That is, historically less developed east and the relatively dominant west becomes a fact for Turkey. The major metropolitan cities of Istanbul, Izmir and Ankara creates centripetal forces with an un-accidental formation of the manufacturing belt in the Marmara District running from Kocaeli, Istanbul and Bursa and spilling over the north-west and south-west of the region. Meanwhile Aegean Region and the West Anatolia together with the mostly western territory of the Mediterranean Region are formed of second set of developed locations. Here different lines of economic activities (such as service based tourism) generate seasonal yet significant opportunities for these western and south western geographies. On contrary Black Sea region (mostly the eastern geography), Eastern and South Eastern Anatolia formed a set of regions with lagging economic and social structures through out the history.

There are possible economic and social explanations behind the inability of the lagging regions to catch up the developed ones. Human capital differences, regional infrastructure capabilities, the extent of the regional economic activity levels and the local labor market conditions can play role in shaping these differences. Henceforth studies dealing with these dimensions of the regional inequalities indicate that these socio-economic concerns share much or less the same faith with the regional income differences that has been observed during the last decades. Filiztekin ${ }^{14}$ focused on the regional unemployment problem of Turkey indicating the persistence of local labor market clusters in different geographies. Meanwhile Elveren ${ }^{15}$ indicate that dispersion of wages has a geographical pattern not only for the pre 2001 period but also for the post 2001 era. Recently Karahasan ${ }^{16}$ argue that economic environment and the activity level of the regions, measured by the new firms' creation has a heteroge-

13 İlhan Tekeli, "UNDP İnasanca Gelişme Raporu: Bölgesel Kalkınma Politikaları Üzerindeki Etkileri”, İnsanca Gelişme Birinci Türkiye Konferansı (Rapor), T.C. Hükümeti ve Milletler Kalkınma Programı İşbirliği (UNDP), 1992, pp. 50-67.

14 Filiztekin, Ibid.

15 Adem Yavuz Elveren, "Wage Inequality in Turkey: Decomposition by Statistical Regions, 1980-2001”, Review of Urban \& Regional Development Studies, 2010, Vol.22, pp.5572.

16 Karahasan, "Dynamics of Regional .... Ibid. 
neous pattern leaving the eastern and especially south eastern Turkey less developed in all lines of production. From a different perspective Bilgel and Karahasan ${ }^{17}$ focus on one of the most remarkable social problems of Turkey, the separatist terrorism in Turkey and measured the regional economic impact on the eastern geography as around $6 \%$ of GDP difference with and without terrorism. That is in general both the scholars investigating the regional income differences but also the ones arguing different socio-economic dimensions of inequalities in Turkey agree that there exists a dichotomy in Turkey leaving the eastern geography in a development trap creating an endogenous circular mechanism that do not allow the regional fundamentals to create a remarkable catch up that decreases the regional inequalities.

\section{Data and Methodology}

This section intends to explain formally the data sources as well as the methodological procedures that will be followed in the empirical part of the analysis.

\subsection{Data}

One important limitation of the study comes from the data availabilities. As discussed among the scholars studying regional inequality issues in Turkey, the lack of regional GDP figures stands as an important barrier against analytical interpretation of the recent trends in regional imbalances. This also makes the case of Turkey non-comparable with other developing and developed countries of its region. Turkish Statistics Institute (TURKSTAT) provides provincial per capita GDP figures from 1987 to 2001. It is also possible to obtain provincial per capita income figures from Özötün ${ }^{18}$ for the period of 1975-1978 and Özötün ${ }^{19}$ for the period 1979-1986. However for the post 2001 period per capita GDP data at provincial level is not reported. This brings a significant and sharp fall in the attempts of the regional scientists to evaluate the different dimensions of regional differences for the post 2001 period. Among them Elveren ${ }^{20}$ and Karahasan ${ }^{21}$ underline the spatial heterogeneity and continue of the dissimilarities for the post 2001 episode. In that sense this study insists on focusing the post 2001 period under these strict data constraints and uses wage income information to assess the path of the inequalities during an era of rapid transformation. The wage income data comes from the TURKSTAT and provided at Nomenclature of Territorial Units for Statistics II (NUTS II) classification covering 26 economic

17 Bilgel F. and Karahasan B.C., Ibid.

18 Erdoğan Özötün, İller İtibariyle Gayri Safi Yurtiçi Hasılası-Kaynak ve yöntemler, 1975-1978, Devlet İstatistik Enstitüsü Yayın No.907, İstanbul, 1980.

19 Erdoğan Özötün, Türkiye Gayri Safi Yurtiçi Hasılasının İller İtibariyle Dağılımı, 1979-1986, İstanbul Ticaret Odası Araştırma Bölümü Yayın No. 1998/8, İstanbul, 1988.

20 Elveren, Ibid.

21 Burhan Can Karahasan, “Türkiye'de Bölgesel Eşitsizlikler: Mekansal Bağlar ve Yerel İstikrarsızlıklar”, Son On Beş Yılda Türkiye Ekonomisi, Eds. Karahasan B.C., Bilgel F. and Soydan A., İstanbul, 2014, Okan Üniversitesi Yayınları, pp.117-143. 
regions. ${ }^{22}$ The first available year of the data is 2003 and the last year of observation is $2008 .^{23}$ Data set also contains information about the number of persons employed, number of local units, turnover and gross investment in tangible assets. The data set can be decomposed at Statistical Classification of Economic Activities in the European Community (NACE 1.1) up to two digits. ${ }^{24}$ Within this research first all economic activities next only manufacturing based economic activities are considered. ${ }^{25}$

\subsection{Regional Dispersion and Spatial Concentration}

The central question of the research is to explain the extent and the path of the regional dissimilarities. Given the traditional approaches and recent advances in regional and spatial science literature a three step approached will be offered in a way to control for the different dimensions of the regional differences. First but not the least the traditional approach offered by Barro and Sala-i Martin ${ }^{26}$ is examined as given in equation 1 . The sigma convergence which is the standard deviation of the logarithm of the wage income is used to assess the path of the dispersion of wages. A second related indicator that can be preferred is the coefficient of variation given in equation 2 , which is the mean standardized dispersion. Both indicators will signal increasing disparities if they go up and fall in inequalities otherwise

$$
\begin{aligned}
\sigma_{t} & =\sqrt{\frac{1}{N} \sum_{i=1}^{N}\left[\ln \left(y_{i t}\right)-\mu_{t}\right]^{2}} \\
\operatorname{CoV} & =\frac{\sigma_{t}}{\mu_{t}}
\end{aligned}
$$

These two indicators are commonly preferred and in a way signal the path of the dispersion, yet will fail to explain the roots of the inequalities. Henceforth the path of the dispersion can be better evaluated by the use of the Theil entropy decomposi-

22 NUTS is the abbreviation for Nomenclature of Territorial Units for Statistics (Nomenclature of Units for Territorial Statistics or Nomenclature des unités territoriales statistiques). It is a geocode standard defining the sub division of countries and accepted by the European Union. Turkey is composed of 12 NUTS I, 26 NUTS II and 81 NUTS III regions.

23 TURKSTAT does not report the 2005 figures, hence analysis will cover years: 2003, 2004, 2006, 2007, and 2008.

24 NACE stands for Nomenclature statistique des activités économiques dans la Communauté européenne.

25 It is possible to replicate the analysis handled within this study for other economic activities as well as the sub-sectors of manufacturing industry. However the central aim of this research is to have a general understanding on the path of the inequalities which is believed to be better handled by using the all economic activities. Meanwhile the specific place of manufacturing industry for Turkey during the industrialization struggles makes its investigation also vital. Detailed decompositions and industrial analysis are left for a different subsequent research.

Barro and Sala-i Martin, Ibid. 
tion. Bourguignon ${ }^{27}$ proposed the Theil Index as given in equation 3, which helps the decomposition of the inequalities for within and between components. $x$ represents the proportion of population to national population while $y$ is the proportion of the wage income. Meanwhile $Y$ is the NUTS I region's total share in wage income and $T$ is the Theil index for the sub divisions (NUTS II regions) in that region. Therefore for the Turkish case first part of equation 3 calculates the NUTS I wage dispersion (between inequalities) then the second part of equation 3 measures the NUTS II variation (within inequalities). The lack of NUTS III level data inhibits the study to focus on local units, however this still gives clues on the locality of the imbalances, which will be also detailed by the spatial data analysis.

$$
T=\sum_{i=1}^{n} y_{i} \log \left(\frac{y_{i}}{x_{i}}\right)+\sum_{g=1}^{n} Y_{g} T_{g}
$$

Finally these first set of analysis can be augmented by questioning the possible spatial concentration among the sub units (NUTS II regions). As discussed in Combes et al. ${ }^{28}$ spatial concentration, which formally measures the extent of the spatial autocorrelation can also be referred as a way to observe spatial similarities (and/or dissimilarities). Here two different spatial concentration statistics are preferred. Moran's I and Geary's C can be used as to assess the extent of the spatial similarities. In case clustering of similar values over a geography is observed these two statistics will yield positive spatial association. Moran's I in equation 4 observes the deviations from the mean whereas Geary's $\mathrm{C}$ in equation 5 focuses on the deviations from different pairs of locations. $n$ is the number regions and $s$ is the summation of the all elements of the weight matrix. This weight matrix will summarize the spatial links among each region. In this study a contiguity weight matrix is used in the entire set of analysis which assigns a value of 1 if two regions are adjacent to each other or 0 otherwise. $^{29}$

$$
\begin{aligned}
I_{i}=\frac{n}{s} \frac{\sum_{i} \sum_{j} w_{i j}\left(x_{i}-\bar{x}\right)\left(x_{j}-\bar{x}\right)}{\sum\left(x_{i}-\bar{x}\right)^{2}} \\
C_{i}=\frac{(n-1)\left(\sum_{i} \sum_{j} w_{i j}\left(x_{i}-x_{j}\right)\right.}{2\left(\sum_{i} \sum_{j} w_{i j}\left(x_{i}-x_{j}\right)^{2}\right)}
\end{aligned}
$$

27 Francois Bourguignon, "Decomposable Income Inequality Measures", Econometrica, Vol.47,No. 4, 1979, 901-920.

28 Pierre-Philippe Combes, Thiery Mayer, and Jacques-François Thisse, Economic Geography, The Integration of Regions and Nations, Princeton University Press, Princeton, 2008.

29 Note that there are other ways of constructing weight matrices. Distance, inverse distance and nearest neighbor based threshold distance weight matrices are some examples. Analysis within this study are also re-done by using other weight matrix specification with qualitatively similar findings. These results are available up request. 


\subsection{Convergence}

The first set of descriptive analysis gives clues on the path as well as the spatial dimension of the regional imbalances in Turkey. In that context contain valuable information for understanding the post 2001 episode. This approach can also be challenged by following Barro and Sala-i Martin ${ }^{30}$. The neo-classic explanation to regional inequalities originates from the traditional convergence model given in equation 6 .

$$
\frac{1}{T} \log \left(\frac{y_{i, t_{o}+T}}{y_{i, t_{0}}}\right)=a+\left(\frac{1-e^{b T}}{T}\right) \log \left(y_{i, t_{o}}\right)+u_{i, t_{0}, t_{0}+T}
$$

The model works with the expectation of the fast growth of initially poor regions for a significant convergence. However in its current form the model assumes a common steady state for each region and in a way disregards the regional heterogeneities. Henceforth it can also be augmented to control for some region specific factors that will allow for different steady states for each region as in equation 7, where $X$ denotes a set of regional controls. This model is regarded as a conditional convergence model unlike the previous model working in absolute terms.

$$
\frac{1}{T} \log \left(\frac{y_{i, t_{o}+T}}{y_{i, t_{0}}}\right)=a+\left(\frac{1-e^{b T}}{T}\right) \log \left(y_{i, t_{o}}\right)+\theta X_{i, t_{0}}+u_{i, t_{0}, t_{0}+T}
$$

These two models evaluate the regional inequalities through a convergence (catch-up) framework estimated in a non-spatial manner at cross-section basis. However it can be further developed by focusing on two different dimensions. One is the possibility of applying the convergence model in a panel setting, second inclusion of spatial links to the convergence equation. There is an evolving discussion on the application of the traditional convergence model in a panel setting. Weeks and $\mathrm{Yao}^{31}$, Badinger et al..$^{32}$ emphasized the use of dynamic panel models while Cuaresme et al. ${ }^{33}$ and $\mathrm{Narro}^{34}$ replicates the traditional convergence panel models by following a fixed effect estimation. In a sense all indicate that results obtained from panel based

30 Barro and Sala-i Martin, Ibid.

31 Melvyn Weeks and J. Yudong Yao, "Provincial Conditional Income Convergence in China, 1953-1997:A Panel Data Approach”, Econometric Reviews, Vol.22, No. 1, 2003, pp.5977.

32 Harald Badinger, Werner Müller and Gabriele Tondl, "Regional Convergence in the European Union, 1985-1999: A Spatial Dynamic Panel Analysis”, Regional Studies, Vol.38, No.3, 2004, pp.241-253.

33 Jesus Crespo Cuerasma, Doris Ritzberger-Grünwald and Maria Antoinette Silgoner, "Growth, convergence and the EU membership", Applied Economics, Vol.40, No. 5, 2008, pp.643-656.

34 Maria C. Cuerva Narro, "Productivity convergence in the European regional agricultures. Determinants of its evolution", European Association of Agricultural Economists, 113th Seminar, Chania, Crete, Greece, 2009. 
convergence models can be quiet different than the cross sectional convergence models. In addition to this mentioned difficulty the short time span of the study (5 years) also plays a dominant difficulty for evaluating some sub components of the convergence models; such as speed of convergence and half-life of convergence to steady state. However as to offer a complementary set of analysis to the initial descriptive observations and in order to have an attempt on constructing a formal approach to the convergence models, a set of representations to the convergence model in a panel setting is offered for Turkey. Equation 8 originates from Lopez-Rodriguez ${ }^{35}$ and tests the impact of the lagged income on the periodical growth of the regions by using fixed and random effect estimations in a panel setting. Meanwhile equation 9 is inspired by Weeks and $\mathrm{Yao}^{36}$ and tests the impact of the lagged income on the current income by estimating a dynamic panel model by using fixed effect, random effect and system generalized method of moments (GMM) methods. Note that both equations are described by neglecting any regional control variables; however some basic regional control variables are going to be introduced during the estimations procedures and will be explained in the next section. Moreover it is worth remarking that the $\beta$ coefficient in equations 8,10 and 11 are different than the one used in Barro and Sala-i Martin $^{37}$, which is the speed of convergence that is donated by $b$ in equations 6 and 7 .

$$
\begin{aligned}
& \frac{1}{T} \log \left(\frac{y_{i, t_{o}+T}}{y_{i, t_{0}}}\right)=a+\beta \log \left(y_{i, t-1}\right)+\varphi_{i}+v_{i, t} \\
& \log \left(y_{i, t}\right)=a+\Omega \log \left(y_{i, t-1}\right)+\varphi_{i}+v_{i, t}
\end{aligned}
$$

Finally a second noteworthy discussion will be on the inclusion of spatial links. As discussed by Anselin ${ }^{38}$ neglecting the impact of spatial regimes may create serious biases in econometric setting. Therefore a set of spatial panel models are also considered on the approach offered in equation 8. Spatial Lag Model (Spatial Autoregressive Model - SAR) assuming spatial dependence over the dependent variable and Spatial Error Model (SEM) assuming spatial spillover from common shocks are defined as in equations 10 and $11 . G$ in equation 10 refers to the regional logarithmic growth reported on the left hand side of the equation 10. Once more these modes are defined without any regional controls, yet will be augmented by some regional factors.

$$
\frac{1}{T} \log \left(\frac{y_{i, t_{o}+T}}{y_{i, t_{0}}}\right)=a+\beta \log \left(y_{i, t-1}\right)+\rho W G+\varphi_{i}+v_{i, t}
$$

35 Jesus Lopez-Rodriguez, "Regional Convergence in the European Union: Results from a Panel Data Model”, Economics Bulletin, Vol. 18, No. 2, 2008, pp. 1-7.

36 Weeks and Yao, Ibid.

37 Barro and Sala-i Martin, Ibid.

38 Luc Anselin, “Thirty Years of Spatial Econometrics”, Papers in Regional Science, Vol.89, 2010, pp.3-25. 


$$
\frac{1}{T} \log \left(\frac{y_{i, t_{o}+T}}{y_{i, t_{0}}}\right)=a+\beta \log \left(y_{i, t-1}\right)+\lambda W \varepsilon_{i, t}+\varphi_{i}
$$

\subsection{Spatial Heterogeneity}

After having done the major building blocks of the analysis, final set of discussions are left to an evolving area of study: spatial heterogeneity. As discussed by Karahasan $^{39}$ the convergence speed can be quiet varying over a geography like Turkey and underlines sizable spatial variability of the speed of convergence for Turkish provinces for the 1975-2001 period. Results show that the significant convergence detected in the traditional models does not always reflect the local realizations. Following Fotheringham et al. ${ }^{40}$; Karahasan ${ }^{41}$ estimated a Geographically Weighted Regression (GWR) indicating very slow convergence in the already lagging regions on the eastern territory. A similar construction is difficulty for the current study, as the unit of observation is NUTS II which is clearly more general with respect to NUTS III disaggregation. In that sense with 26 observations a GWR type of model will have less reliable results. However as the spatial dichotomy is an issue of concern a basic spatial data analysis technique is followed as to question the extent of the possible catch up of the poor locations. Equation 12 is the Local Indicator of Spatial Association (LISA) developed by Anselin ${ }^{42}$. It gives the local decomposition of the global Moran's I. In a way in case regions with values higher than the average are clustered together a hot spot of high regions, in case regions with values lower than the average are clustered together a cold spot of low regions are going to be observed. There are also local instabilities, where an outlier with high or low values may persist deviating from its geography. Calculation of the LISA in that sense may contain sizable information for the path of the regional imbalances. Here an important concern is the significance level of the LISA scores. As there will be a LISA score for each cross section, its local significance can be of concern. However inspired by the recent discussions of Monastiriotis $^{43}$ it is also possible to disregard the significance of the LISA scores and to consider each cross section while evaluating the decomposition of the global spatial autocorrelation. Here the study will follow a similar understanding while evaluating the LISA scores for Turkey.

$$
I_{i}=\left(x_{i}-\bar{x}\right) \sum_{j} w_{i j}\left(x_{j}-\bar{x}\right)
$$

39 Karahasan “Türkiye'de Bölgesel Eşitsizlikler...Ibid.

40 A. Stewart Fotheringham, Chris Brunsdon and Martin Charlton, Geographically Weighted Regression: The Analysis of Spatially Varying Relationships, Wiley, 2002.

41 Karahasan “Türkiye'de Bölgesel Eşitsizlikler...Ibid.

42 Luc Anselin, "Local Indicators of Spatial Association-LISA", Geographical Analysis, Vol. 27, No.2, 1995, pp. 93-115.

43 Vassilis Monastiriotis, "Examining the consistency of spatial association patterns across socio-economic indicators: an application to the Greek regions", Empirical Economics, Vol. 37, 2009, pp.25-49. 


\section{Findings}

In line with the constructed framework first set of analysis are carried out as to understand the extent of the regional dispersion and variation. Wage income data is the per employment salary distribution in each NUTS II regions at constant prices. Table 4.1 contains the sigma convergence, coefficient of variation and the Theil Index calculations for all industries and for only the manufacturing industry. An overall assessment of the first set of analysis indicate a fall in each statistics signaling the possible fall of wage income inequalities at NUTS II disaggregation. More detailed examination of these figures indicate that for manufacturing based production wage income inequalities seems to be higher yet tend to converge to total industrial wage income dispersion within the short time span investigated. A second remarkable issue is the decomposition of the inequalities reminding that inequalities between the NUTS I geographical regions seems to be dominating the within variation, that is the dissimilarities between the NUTS II sub-divisions. This finding is in a way interesting as it could be expected to have higher variation at more local level (for instance at NUTS II or NUTS III disaggregation); yet it could also be the case that strong spatial ties among NUTS II and/or NUTS III regions may create clusters that tend to generate wider regions (both in terms of administrative but also in terms of geographical boundaries) deviating between each other while getting more similar within their territories.

Table 4.1: Regional Inequalities

\begin{tabular}{|c|c|c|c|c|c|}
\hline \multicolumn{6}{|c|}{ Panel A: All Industries } \\
\hline & \multirow{2}{*}{$\begin{array}{c}\text { Sigma } \\
\text { Convergence }\end{array}$} & \multirow{2}{*}{$\begin{array}{l}\text { Coefficient of } \\
\text { Variation }\end{array}$} & \multicolumn{3}{|c|}{$\begin{array}{c}\text { Theil } \\
\text { Decomposition }\end{array}$} \\
\hline & & & $\begin{array}{l}\text { Theil } \\
\text { Index }\end{array}$ & $\begin{array}{c}\text { Within } \\
\%\end{array}$ & $\begin{array}{c}\text { Between } \\
\%\end{array}$ \\
\hline 2003 & 0.328 & 0.328 & 0.048 & $27 \%$ & $73 \%$ \\
\hline 2004 & 0.291 & 0.318 & 0.045 & $23 \%$ & $77 \%$ \\
\hline 2006 & 0.315 & 0.319 & 0.047 & $31 \%$ & $69 \%$ \\
\hline 2007 & 0.257 & 0.277 & 0.035 & $23 \%$ & $77 \%$ \\
\hline 2008 & 0.278 & 0.299 & 0.040 & $37 \%$ & $63 \%$ \\
\hline \multicolumn{6}{|c|}{ Panel B: Manufacturing } \\
\hline & \multirow{2}{*}{$\begin{array}{c}\text { Sigma } \\
\text { Convergence }\end{array}$} & \multirow{2}{*}{$\begin{array}{l}\text { Coefficient of } \\
\text { Variation }\end{array}$} & \multicolumn{3}{|c|}{$\begin{array}{c}\text { Theil } \\
\text { Decomposition }\end{array}$} \\
\hline & & & $\begin{array}{l}\text { Theil } \\
\text { Index }\end{array}$ & $\begin{array}{c}\text { Within } \\
\%\end{array}$ & $\begin{array}{c}\text { Between } \\
\%\end{array}$ \\
\hline 2003 & 0.813 & 0.449 & 0.114 & $52 \%$ & $48 \%$ \\
\hline 2004 & 0.351 & 0.350 & 0.059 & $32 \%$ & $68 \%$ \\
\hline 2006 & 0.321 & 0.323 & 0.050 & $36 \%$ & $64 \%$ \\
\hline 2007 & 0.299 & 0.300 & 0.043 & $24 \%$ & $76 \%$ \\
\hline 2008 & 0.293 & 0.300 & 0.043 & $37 \%$ & $63 \%$ \\
\hline
\end{tabular}

Source: TURKSTAT, author's own calculations 
After evaluating the variation a second noteworthy issue is on the identification of the spatial concentration; that is the extent of the spatial similarities among the NUTS II regions in terms of wage income dispersion. Table 4.2 summarizes the spatial clustering results.

Table 4.2: Spatial Concentration

\begin{tabular}{|c|c|c|c|c|}
\hline & \multicolumn{2}{|c|}{ Panel A: All Industries } & \multicolumn{2}{|c|}{ Panel B: Manufacturing } \\
\hline & Moran's I & Geary's C & Moran's I & Geary's C \\
\hline 2003 & $\begin{array}{l}0.137^{*} \\
(0.121)\end{array}$ & $\begin{array}{c}0.761^{* *} \\
(0.145)\end{array}$ & $\begin{array}{l}-0.063 \\
(0.119)\end{array}$ & $\begin{array}{c}0.951 \\
(0.152)\end{array}$ \\
\hline 2004 & $\begin{array}{c}0.242 * * * \\
(0.118)\end{array}$ & $\begin{array}{c}0.620 * * * \\
(0.159)\end{array}$ & $\begin{array}{c}0.039 \\
(0.114)\end{array}$ & $\begin{array}{c}0.912 \\
(0.177)\end{array}$ \\
\hline 2006 & $\begin{array}{c}0.311 * * * \\
(0.121)\end{array}$ & $\begin{array}{c}0.577 * * * \\
(0.146)\end{array}$ & $\begin{array}{c}0.105 \\
(0.116)\end{array}$ & $\begin{array}{c}0.854 \\
(0.167)\end{array}$ \\
\hline 2007 & $\begin{array}{c}0.404 * * * \\
(0.119)\end{array}$ & $\begin{array}{c}0.482 * * * \\
(0.155)\end{array}$ & $\begin{array}{l}0.119^{*} \\
(0.118)\end{array}$ & $\begin{array}{c}0.799 \\
(0.158)\end{array}$ \\
\hline 2008 & $\begin{array}{c}0.361 * * * \\
(0.121)\end{array}$ & $\begin{array}{c}0.480 * * * \\
(0.143)\end{array}$ & $\begin{array}{c}0.359 * * * \\
(0.122)\end{array}$ & $\begin{array}{c}0.579 * * * \\
(0.140)\end{array}$ \\
\hline
\end{tabular}

Notes: $* * *, * *$ and $*$ indicates significance at $1 \%, 5 \%$ and $10 \%$ respectively.

Source: TURKSTAT, author's own calculations

Findings indicate sizable spatial concentration of the all lines of industrial activities at NUTS II disaggregation. Moreover figures indicate increasing spatial similarities and concentration within the time span considered. Meanwhile his spatial dependence is observed to be lower for manufacturing production at NUTS II level however it also tends to increase towards to the end of the analysis period. In general all these underline that spatial dependence matters even once the wage income dispersion is investigated at NUTS II disaggregation. It is however true that NUTS II separation is rather broad compared to NUTS III or more detailed separation of the regions. In a way both the descriptive variation analysis as well as the spatial concentration analysis fail to explain the local variations and spatial ties within the NUTS II territories, yet data availabilities prevent a more detailed discussion on the matter.

After having idea on the variation, dispersion as well as spatial concentration of the wage income data, following set of analysis intends to construct a formal model to evaluate the extent of the possible convergence among the NUTS II regions even within a relatively short time period. Table 4.3 contains the results of the first set of panel models with and without spatial effects. At this stage regional different properties are not considered hence results given in table 4.3 in a way is in absolute sense with the expectation of common steady states for each NUTS II regions. 
Table 4.3: Absolute Convergence Models

\begin{tabular}{|c|c|c|c|c|}
\hline \multicolumn{5}{|c|}{ Non-Spatial Models } \\
\hline & \multicolumn{2}{|c|}{ Panel A: All Industries } & \multicolumn{2}{|c|}{ Panel B: All Manufacturing } \\
\hline & FE & RE & FE & RE \\
\hline$\beta$ & $\begin{array}{c}-0.152 * * * \\
(0.018)\end{array}$ & $\begin{array}{c}-0.043 * * * \\
(0.011)\end{array}$ & $\begin{array}{c}-0.188 * * * \\
(0.012) \\
\end{array}$ & $\begin{array}{c}-0.162 * * * \\
(0.028)\end{array}$ \\
\hline \multicolumn{5}{|c|}{ Spatial Fixed Effect Models } \\
\hline & \multicolumn{2}{|c|}{ Panel A: All Industries } & \multicolumn{2}{|c|}{ Panel B: All Manufacturing } \\
\hline & SAR & SEM & SAR & SEM \\
\hline$\beta$ & $\begin{array}{c}-0.134 * * * \\
(0.041 \\
\end{array}$ & $\begin{array}{c}-0.148 * * * \\
(0.043) \\
\end{array}$ & $\begin{array}{c}-0.181 * * * \\
(0.019) \\
\end{array}$ & $\begin{array}{c}-0.188 * * * \\
(0.012) \\
\end{array}$ \\
\hline$\rho$ & $\begin{array}{c}0.264 * * * \\
(0.004)\end{array}$ & - & $\begin{array}{c}0.257 * * * \\
(0.002)\end{array}$ & - \\
\hline$\lambda$ & - & $\begin{array}{c}0.041 * * \\
(0.018)\end{array}$ & - & $\begin{array}{l}-0.010 \\
(0.015)\end{array}$ \\
\hline \multicolumn{5}{|c|}{ Spatial Random Effect Models } \\
\hline & \multicolumn{2}{|c|}{ Panel A: All Industries } & \multicolumn{2}{|c|}{ Panel B: All Manufacturing } \\
\hline & SAR & SEM & SAR & SEM \\
\hline$\beta$ & $\begin{array}{c}-0.035^{* *} * \\
(0.016) \\
\end{array}$ & $\begin{array}{c}-0.040 * * \\
(0.020)\end{array}$ & $\begin{array}{c}-0.147 * * * \\
(0.050)\end{array}$ & $\begin{array}{c}-0.175^{* * *} * \\
(0.027)\end{array}$ \\
\hline$\rho$ & $\begin{array}{c}0.269 * * * \\
(0.003)\end{array}$ & - & $\begin{array}{c}0.261^{* * *} \\
(0.002)\end{array}$ & - \\
\hline$\lambda$ & - & $\begin{array}{c}0.038 \\
(0.024)\end{array}$ & - & $\begin{array}{l}-0.025 \\
(0.021)\end{array}$ \\
\hline
\end{tabular}

Notes: $* * *, * *$ and $*$ indicates significance at $1 \%, 5 \%$ and $10 \%$ respectively

In that sense results given in table 4.3 are interesting. First in all of the specifications it is remarkable that there exists a negative relationship between the previous year's wage income and the annual growth of the wage income figures. This can be regarded as some sign of catch up between lagging and leading NUTS II regions. It is also important to figure out that for the spatial specifications the magnitude of the catch-up is higher. Additionally for these models spatial links over the annual wage income growth is existent both for fixed effect as well as random effect models. Yet spatial spillover from the regional common shocks seems to be weaker and mostly inexistent for the random effect models. These general findings are also applicable for the manufacturing based production. The only minor differences is that for the random effect specifications the magnitude of the previous years' wage income is relatively smaller for the random effect models estimated for the all industrial production. Yet given that fixed effect estimations are mostly more reliable within the scope of this research, this seems to be a negligible concern. Next these models are augmented by taking into consideration two vital regional properties. Among various controls that could be preferred regional average firm size and average investment (both are 
per employment) are included as control variables into the estimated models. That is the first set of absolute convergence analysis are transformed into a conditional sense and the results are reported in table 4.4 .

Table 4.4: Conditional Convergence Models

\begin{tabular}{|c|c|c|c|c|}
\hline \multicolumn{5}{|c|}{ Non-Spatial Models } \\
\hline & \multicolumn{2}{|c|}{ Panel A: All Industries } & \multicolumn{2}{|c|}{ Panel B: All Manufacturing } \\
\hline & FE & RE & FE & RE \\
\hline$\beta$ & $\begin{array}{c}-0.152 * * * \\
(0.018)\end{array}$ & $\begin{array}{c}-0.043 * * * \\
(0.011)\end{array}$ & $\begin{array}{c}-0.193 * * * \\
(0.007)\end{array}$ & $\begin{array}{r}-0.176^{* * * *} \\
(0.022)\end{array}$ \\
\hline \multicolumn{5}{|c|}{ Spatial Fixed Effect Models } \\
\hline & \multicolumn{2}{|c|}{ Panel A: All Industries } & \multicolumn{2}{|c|}{ Panel B: All Manufacturing } \\
\hline & SAR & SEM & SAR & SEM \\
\hline$\beta$ & $\begin{array}{c}-0.134 * * * \\
(0.041 \\
\end{array}$ & $\begin{array}{c}-0.148 * * * \\
(0.043)\end{array}$ & $\begin{array}{c}-0.194 * * * \\
(0.009) \\
\end{array}$ & $\begin{array}{c}-0.193 * * * \\
(0.007)\end{array}$ \\
\hline$\rho$ & $\begin{array}{c}0.264 * * * \\
(0.004)\end{array}$ & - & $\begin{array}{c}0.257 * * * \\
(0.002)\end{array}$ & - \\
\hline$\lambda$ & - & $\begin{array}{c}0.041 * * \\
(0.018)\end{array}$ & - & $\begin{array}{c}0.013 \\
(0.034)\end{array}$ \\
\hline \multicolumn{5}{|c|}{ Spatial Random Effect Models } \\
\hline & \multicolumn{2}{|c|}{ Panel A: All Industries } & \multicolumn{2}{|c|}{ Panel B: All Manufacturing } \\
\hline & SAR & SEM & SAR & SEM \\
\hline$\beta$ & $\begin{array}{c}-0.035^{* * *} \\
(0.016)\end{array}$ & $\begin{array}{c}-0.040 * * \\
(0.020)\end{array}$ & $\begin{array}{c}-0.167 * * * \\
(0.037)\end{array}$ & $\begin{array}{c}-0.182 * * * \\
(0.022)\end{array}$ \\
\hline$\rho$ & $\begin{array}{c}0.269 * * * \\
(0.003)\end{array}$ & - & $\begin{array}{c}0.260 \\
(0.002) \\
\end{array}$ & - \\
\hline$\lambda$ & -- & $\begin{array}{c}0.038 \\
(0.024)\end{array}$ & & $\begin{array}{c}0.022 \\
(0.037)\end{array}$ \\
\hline
\end{tabular}

Notes: $* * *, * *$ and $*$ indicates significance at $1 \%, 5 \%$ and $10 \%$ respectively

Results given in table 4.4 are much or less in line with the previous set of findings from the absolute models. There is only a minor increase in terms of the magnitude of the conditional models however in general for both total industry as well as just for manufacturing industry there seems to be some sort of a catch up among the NUTS II regions in Turkey. Here it is noteworthy that the convergence observed from panel data models are in a way higher with respect to the convergence observed among the NUTS III regions for the pre 2001 period. This is in a way expected as it is already documented by Lopez Rodrigue ${ }^{44}$ that there seems to be sizable differences between panel and cross section estimation of the convergence models. 
Finally following the already mentioned discussion final set of convergence models are estimated in a dynamic manner; that is new set of models aim to explain the NUTS II wage income by controlling for the wage income observed in the previous year. This will help to evaluate not only the convergence but also the persistence of the wage income dispersion. Results are given in table 4.5. These results are interesting in a way, mostly against the initial set of findings from the panel data estimation of the traditional convergence approach. Focusing on the system GMM results, findings indicate a significant and positive coefficient for the previous year's wage income for absolute models. This in a way signals out a divergence and persistence for the regional distribution of the wage income. Moreover for the conditional models, the significance of the impact is observed to disappear even though it is still positive. In a way this seems to be an important sign on the possible over estimation of the convergence observed in the first set of panel models that replicated the traditional cross-section convergence in a panel setting. However following the concerns of Weeks and $\mathrm{YaO}^{45}$ estimation of a dynamic panel convergence models yields some critical findings on the matter.

Table 5: Alternative Models in a Dynamic Panel Setting

\begin{tabular}{|c|c|c|c|c|c|c|}
\hline \multicolumn{7}{|c|}{ Absolute Models } \\
\hline & \multicolumn{3}{|c|}{ Panel A: All Industries } & \multicolumn{3}{|c|}{ Panel B: All Manufacturing } \\
\hline & FE & RE & $\begin{array}{c}\text { Sys } \\
\text { GMM }\end{array}$ & FE & $\mathbf{R E}$ & $\begin{array}{c}\text { Sys } \\
\text { GMM }\end{array}$ \\
\hline$\Omega$ & $\begin{array}{l}-0.011 \\
(0.215)\end{array}$ & $\begin{array}{c}0.846^{* * * *} \\
(0.047)\end{array}$ & $\begin{array}{c}0.927 * * * \\
(0.066)\end{array}$ & $\begin{array}{c}0.115 \\
(0.481)\end{array}$ & $\begin{array}{c}0.765 \\
(0.070)\end{array}$ & $\begin{array}{c}1.053^{* * * *} \\
(0.128)\end{array}$ \\
\hline \multicolumn{7}{|c|}{ Conditional Models } \\
\hline & \multicolumn{3}{|c|}{ Panel A: All Industries } & \multicolumn{3}{|c|}{ Panel B: All Manufacturing } \\
\hline & $\mathrm{FE}$ & RE & $\begin{array}{c}\text { Sys } \\
\text { GMM }\end{array}$ & FE & $\mathbf{R E}$ & $\begin{array}{c}\text { Sys } \\
\text { GMM }\end{array}$ \\
\hline$\Omega$ & $\begin{array}{c}0.001 \\
(0.199)\end{array}$ & $\begin{array}{c}0.330^{* * * *} \\
(0.125)\end{array}$ & $\begin{array}{c}0.078 \\
(0.427)\end{array}$ & $\begin{array}{c}0.068 \\
(0.480)\end{array}$ & $\begin{array}{c}0.632 \\
(0.060)\end{array}$ & $\begin{array}{c}0.794 * * * \\
(0.165)\end{array}$ \\
\hline
\end{tabular}

Notes: $* * *, * *$ and $*$ indicates significance at $1 \%, 5 \%$ and $10 \%$ respectively

Overall our results indicate that even though the traditional convergence approach by relating the initial wage income with the growth of wage income in a panel setting yields results in favor of sizable convergence; application of the model in a dynamic panel setting underlines the persistence of the wage income gaps reminding that it is the already high wage income regions that rank at the upper part of the distribution today. Henceforth a more detailed analysis is observed to be necessary as the dynamic panel model results indicating the strong persistence of the wage income differences can well be a reason as well as the results of an ongoing spatial heterogeneity. 
In order to better apprehend this matter, the first and the last year of the investigation period is considered. NUTS II regions are classified based on the spatial variability of the spatial concentration that has been calculated and summarized in table 4.2. The so-called LISA decomposition is applied and the contribution of each region to the global spatial measure of Moran's I is investigated. Results for the final set of spatial heterogeneity analysis are given in figures 4.1 and 4.2 for all industries and just for manufacturing industry respectively. In each case four group of regions are formed. Based on the spatial dependence among the NUTS II regions, each region is classified based on its position (and inevitably neighbor regions' position) with respect to the country average. Regions denoted as red hot spots are the high-high clusters composed of regions with above country average wage income whereas dark blue regions are the cold spots formed of regions with a wage income below the country average. Meanwhile two set of outlier regions are formed; light blue regions are the one with low wage income but surrounded by high wage income regions and the pink regions are the ones with relatively high wage income but surrounded by relatively low wage income regions. In a way this analysis helps the examination of both the spatial regimes as well as the spatial heterogeneities within the distribution.

First starting with the examination of all industrial activities in figure 4.1, findings underline that out of the 26 NUTS regions the number of regions within the high wage income cluster is 8 in both years. Only two movements are detected from 2003 to 2008 for the high wage income regions: One is the move of Izmir in the Aegean Region from high income cluster to high income outlier; second is the move of Zonguldak NUTS II sub-division in the Black Sea Region from low income cluster to high income clusters. However most remarkable change in the distribution comes from the high outliers mostly in the eastern Turkey. 5 of the high income regions acting as outliers in the eastern Turkey moved to the low income group from 2003 to 2008. Meanwhile low income outliers in the central and southern Turkey moved towards the low income group during the same period. In general these finding are crucial as they indicate that there are different spatial regimes in Turkey regarding the distribution of wage income covering the whole industries. It is also clear that there tends to exists a spatial dichotomy that in a way makes the eastern geography less developed. Moreover unlike the first set of descriptive analysis of inequalities as well as the first set of convergence models, here results indicate that it is inaccurate to mention a strong convergence among the NUTS two regions once wage income data for all industries are considered. Rather it seems that results of the dynamic panel model, indicating the persistence of wage income data is more reliable. 


\section{Figure 4.1: Spatial Regimes and Regional Heterogeneities}

(a) All Industries 2003
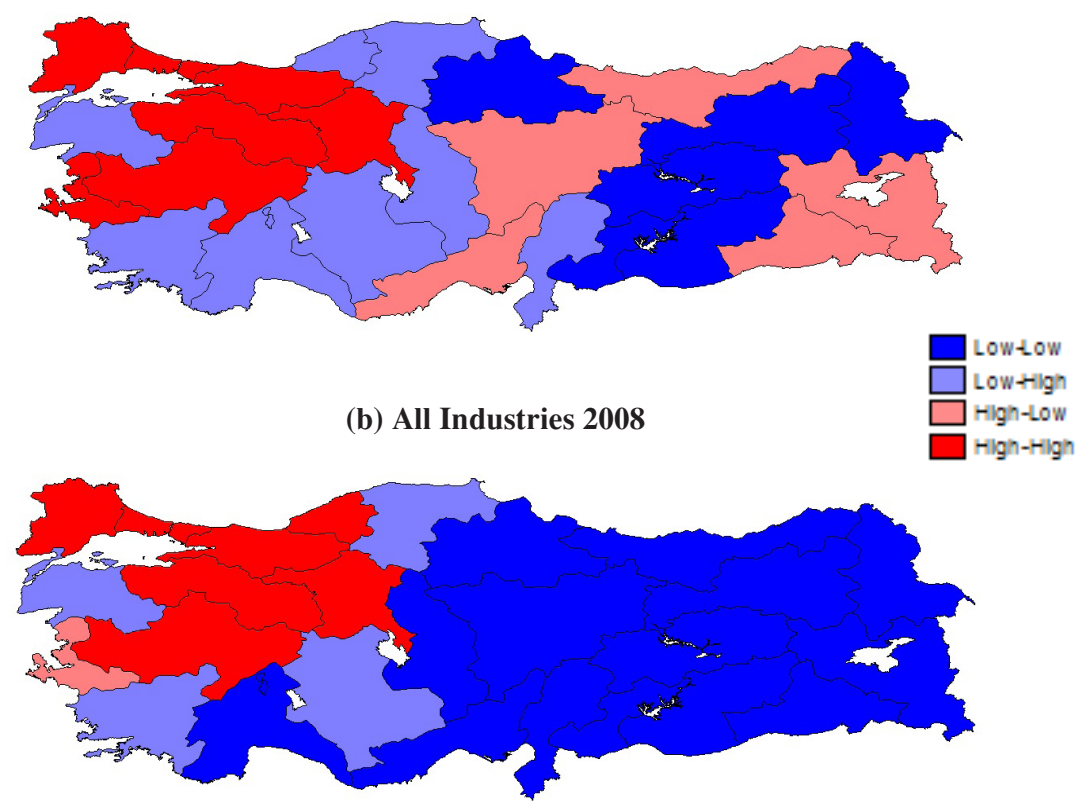

Source: TURKSTAT, author's own calculations

Finally a similar representation is also carried out for the manufacturing industry. In a way even the spatial concentration of the manufacturing industry is observed to be weaker at NUTS II disaggregation (with respect to the all industries) in general still it is vital to consider if there are any similarities at the regional level that constructs diverse spatial regimes for the period under concern. Figure 4.2 gives the spatial regimes for the wage income in manufacturing production. Once more the movement for the high wage income regions seems to be limited. In general there seems to be a persistent cluster around the Marmara region spreading out towards North-West Marmara and Central, Western Anatolia. There are also some signs of mobility for high and low wage income outliers which are acting as transition regions. However again most remarkable mobility within the distribution comes from the low wage income regions; it is observed that from 2003 to 20085 high wage income NUTS II region moves towards low wage income clusters in the eastern Turkey. In a way making the spatial dichotomy even more visible again signaling out the deepening of the spatial heterogeneity in Turkey. 


\section{Figure 2: Spatial Regimes and Regional Heterogeneities}

(a) Manufacturing 2003

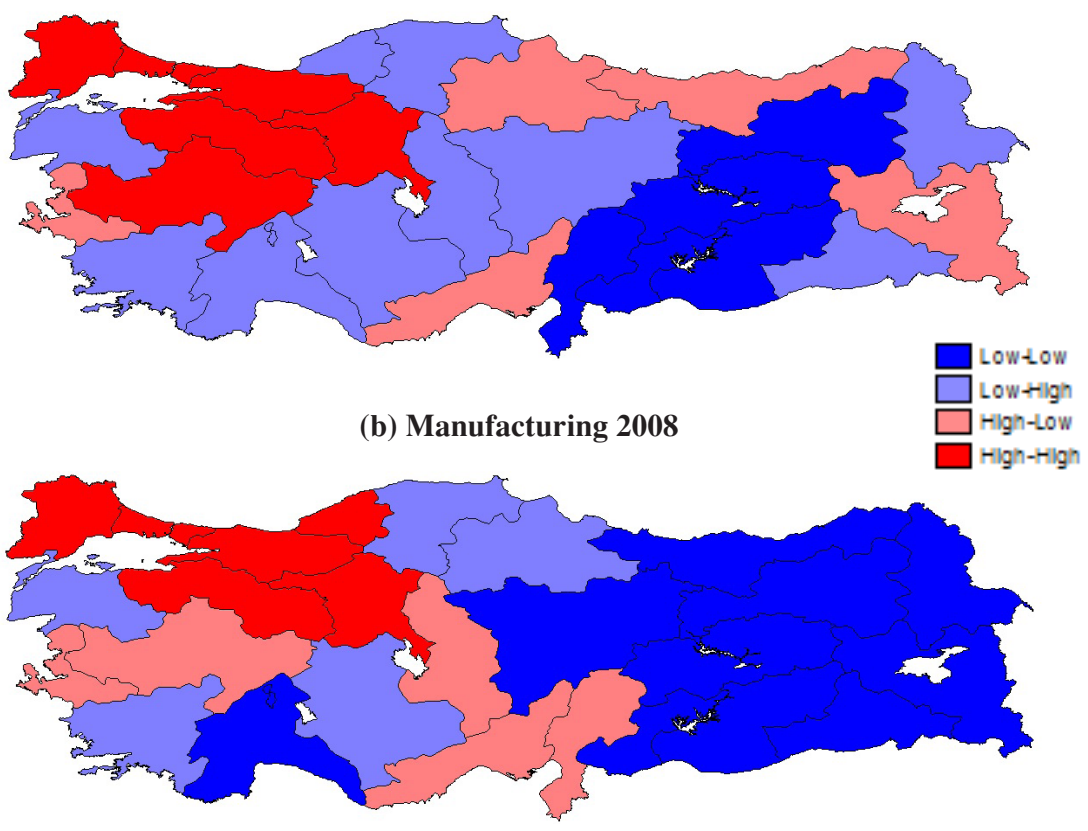

Source: TURKSTAT, author's own calculations

As a final discussion; inevitably results of the study is unable to control for a number of points. As discussed during the data introduction, lack of regional income data for the post 2001 period makes a one to one comparison of the analysis with the previous periods difficult. Moreover the disaggregation level of the study which is NUTS II is in a sense covers a large surface both in terms of geography but also in terms of administrative boundaries. This makes the investigation of the more local dispersions and variations difficult. Yet the attempt of the existing study is to find a formal way to examine the regional inequality patterns of the post 2001 period, which is believed to open up new influential discussion among the scholars.

\section{Conclusion}

Regional inequalities is one of the most important socio-economic concerns of Turkey for ages. Evidence from the late planned period and the rapid transformation era of early 1980 witnessed a worsening in the regional differences. Our knowledge on the path of the regional income gaps which is restricted to the early 2000s remark that the dichotomy observed among the regions in Turkey leave the eastern geography less developed with respect to the western part of the country. Originating from the persistence of the regional imbalances, this study explores to the developments on the 
side of regional imbalances for the post 2001 period during which Turkey have been witnessing a new wing of transformation.

Using wage income data available for the years 2003 to 2008 (excluding 2005) early set of evidence indicates that NUTS II regions of Turkey is realizing some signs of sigma convergence and a fall in the variation of the wage income differences. This early finding is also confronted by the use of panel data base traditional neo-classic convergence models. It seems also to be the case that spatial ties exists within the models as in most of the cases the spatial dependence parameter of the models have explanatory power in explaining the regional wage income growth differences. It is however also remarkable that dynamic panel models' results are not one to one in line with the first set of panel models. In a way the complexity of the estimation of the convergence model in a panel setting and the discussion among the scholars on the matter is crucial. Even the regional growth of wage income is inversely related with the level of wage income in the previous period, the level of current wage income is observed to be positively associated with the previous wage income level of the regions. In a way this brings additional concerns as the time span of the panel model analysis is restricted to 5 years coming from strict data availabilities. In that sense it is possible to argue that given the short time dimension and the inconsistency between the different approaches of measuring convergence it seems to be blurry to have a clear argument on the long run nature of the relationship between regional growth and the initial conditions, thus convergence. However it is still possible to argue that spatial ties are existent, regional growth seems to be shifting to some relatively less developed (in terms of wage income) regions, yet the short term dynamics indicate that still the high wage income regions are the ones that used to have higher wage income formerly. This reminds the final possible property of the regional wage income dispersion, which is the extent of the spatial heterogeneity. In line with this concern, leaving the convergence modelling on one side and returning to the initial set of spatial concentration analysis; decomposition of the spatial dependence is implemented. The idea is to observe the local variations of the spatial dependence. That is final set of analysis focuses on the local clustering of regions in a way to assess the formation of high and low wage income regions. Findings are interesting from a couple of different points. First of all results indicate that as of year 2003 and 2008 for both all industries as well as only for manufacturing industry, there is a persistent regional duality leaving the eastern regions well behind the western geography. In all cases the cluster of regions around the Marmara District is importunate signaling the possible agglomeration as well as externalities of the geography. More interestingly for the all industries there seems to be a collapse among 5 of the regions; which belong to a high wage income group as of 2003 but moved to a low wage income group in 2008. These results from all industries are also comparable with similar findings obtained for the manufacturing industry.

Overall it is remarkable that the post 2001 era, through which Turkey realizes rapid yet slowing growth, NUTS II regions seems to benefit unequally from the national developments. In a way returning back to the early remarks on the attitude of the policy makers towards the regional inequality issues, it is the case that desired results cannot be sustained to decrease the regional differences. Moreover it seems to be the case that spatial regimes that belongs to the pre 2001 period still exists, re- 
minding once more that a more flexible and less centralized regional policy making is necessary. Even this could be sustained by the use of institutional tools like Regional Development Agencies (RDAs) it should also be noted that an active coordination between regional institutions and policies is getting more prominent given the accelerating spatial links and heterogeneities. It is one of the remaining objectives of this research to open up new discussions on the regional inequality problem by reminding both policy makers and scholars that a long run sustainable growth and development at the national scale is very difficult to be sustained unless different segments of the society both in terms of class as well as geographic locations benefit from similar extents from the overall national developments. 


\section{References}

ANSELIN Luc, “Thirty Years of Spatial Econometrics”, Papers in Regional Science, Vol.89, 2010, pp.3-25.

ANSELIN Luc, "Local Indicators of Spatial Association-LISA", Geographical Analysis, Vol. 27, No.2, 1995, pp. 93-115.

BADINGER Harald, MÜLLER Werner and TONDL Gabriele, "Regional Convergence in the European Union, 1985-1999: A Spatial Dynamic Panel Analysis", Regional Studies, Vol.38, No.3, 2004, pp.241-253.

BARRO Robert J. and SALA-I MARTIN Xavier, "Convergence”, Journal of Political Economy, Vol.100, No.2, 1992, pp.223-251.

BILLGEL Firat and KARAHASAN Burhan Can, "The Economic Costs of Separatists Terrorism in Turkey", Journal of Conflict Resolution, DOI: 10.1177/0022002715576572, 2015.

BOURGUIGNON Francois, "Decomposable Income Inequality Measures", Econometrica, Vol.47,No. 4, 1979, 901-920.

COMBES Pierre-Philippe, MAYER Thiery, and THISSE Jacques-François, Economic Geography, The Integration of Regions and Nations, Princeton University Press, Princeton, 2008.

CUERASMA Jesus Crespo, RITZBERGER-GRUNWALD Doris and SILGONER Maria Antoinette, "Growth, convergence and the EU membership", Applied Economics, Vol.40, No. 5, 2008, pp.643-656.

DOĞRUEL Fatma, “Türkiye'de Bölgesel Politikalar”, Değişen Türkiye Dönüşen Mekan, ,Ed. A. Eraydın, 2006, Dost Kitapevi Yayınları, pp. 164-195.

DOĞRUEL Fatma, Bölgesel Kalkınma ve Kalkınma Ajansları, TÜRKONFED Yayınları, 2012.

DOĞRUEL Fatma and DOĞRUEL Suut, “Türkiye'de Bölgesel Gelir Farklılıkları ve Büyüme”, İktisat Üzerine Yazılar I Küresel Düzen: Birikim, Devlet ve Sınıflar Korkut Boratav’a Armağan, Eds. A.Köse, F.Şenses, E. Yeldan, 2003.

ELVEREN Adem Yavuz, "Wage Inequality in Turkey: Decomposition by Statistical Regions, 1980-2001", Review of Urban \& Regional Development Studies, Vol.22, 2010, pp.55-72.

FILIZTEKİN Alpay, "Regional Unemployment in Turkey", Papers in Regional Science, Vol.88, No.4, 2009, pp.863-878.

FOTHERINGHAM A. Stewart, BRUNSDON Chris and CHARLTON Martin, Geographically Weighted Regression: The Analysis of Spatially Varying Relationships, Wiley, 2002.

GEZİCI Ferhan and HEWINGS Geoffrey J.D., "Regional Convergence and Economic Performance of Peripheral Areas in Turkey", Review of Urban \& Regional Development Studies, Vol.16, No.2, 2004, pp.113-132. 
KARAHASAN Burhan Can and UYAR Emrah, "Spatial Distribution of Education and Regional Inequalities in Turkey", Munich Personal RePEc Archive, No.30130, 2009.

KARAHASAN Burhan Can, “Türkiye’de Bölgesel Eşitsizlikler: Mekansal Bağlar ve Yerel İstikrarsızlıklar”, Son On Beş Yılda Türkiye Ekonomisi, Eds. Karahasan B.C., Bilgel F. and Soydan A., İstanbul , 2014, Okan Üniversitesi Yayınları, pp.117-143.

KARAHASAN Burhan Can, "Dynamics of Regional New Firm Formation in Turkey”, Review of Urban \& Regional Development Studies, Vol. 27, No.1, 2015, pp. 18-39.

LOPEZ-RODRIGUEZ Jesus, "Regional Convergence in the European Union: Results from a Panel Data Model”, Economics Bulletin, Vol. 18, No. 2, 2008, pp. 1-7.

MONASTIRIOTIS Vassilis, "Examining the consistency of spatial association patterns across socio-economic indicators: an application to the Greek regions", Empirical Economics, Vol. 37, 2009, pp.25-49.

NARRO Maria C. Cuerva, "Productivity convergence in the European regional agricultures. Determinants of its evolution", European Association of Agricultural Economists, 113th Seminar, Chania, Crete, Greece, 2009.

ÖZÖTÜN Erdoğan, İller İtibariyle Gayri Safi Yurtiçi Hasılası-Kaynak ve yöntemler, 1975-1978, Devlet İstatistik Enstitüsü Yayın No.907, İstanbul, 1980.

ÖZÖTÜN Erdoğan, Türkiye Gayri Safi Yurtiçi Hasılasının İller İtibariyle Dağılımı, 1979-1986, İstanbul Ticaret Odası Araştırma Bölümü Yayın No. 1998/8, İstanbul, 1988.

ŞENSES Fikret, "Economic Crisis as an Instigator of Distributional Conflict: The Turkish Case in 2001", The Turkish Economy in Crisis, Eds. Öniş Z. and Rubin B., Routledge, 2003, pp. 92-120.

TEKELİ İlhan, “UNDP İnasanca Gelişme Raporu: Bölgesel Kalkınma Politikaları Üzerindeki Etkileri”, İnsanca Gelişme Birinci Türkiye Konferansı (Rapor), T.C. Hükümeti ve Milletler Kalkınma Programı İşbirliği (UNDP), 1992, pp. $50-67$.

WEEKS Melvyn and YAO J. Yudong, "Provincial Conditional Income Convergence in China, 1953-1997:A Panel Data Approach”, Econometric Reviews, Vol.22, No. 1, 2003, pp.59-77.

YEŞİLYURT Filiz and ELHORST J. Paul, “A Regional Analysis of Inflation Dynamics in Turkey", The Annals of Regional Science, Vol.52, 2014, 1-17.

YILDIRIM Julide and ÖCAL Nadir, "Income Inequality and Economic Convergence in Turkey”, Transition Studies Review, Vol.13, No.3, 2006, pp.559-568. 